\title{
Significance of Elating the Entrepreneurial Initiatives through Education among MBA Students
}

\author{
Dr. A.Abirami \\ Assistant Professor, LEAD \\ College of Management, Dhoni, \\ Palkkad, Kerala
}

\author{
Dr. A.Mahadevan \\ Professor, Sri Ganesh School \\ of Management, Salem, \\ Tamilnadu, India
}

\author{
Dr. A.Thangaraja \\ Assistant Professor, LEAD \\ College of Management, Dhoni, \\ Palkkad, Kerala
}

\section{ABSTRACT}

Starting from a century ago, everyone has seen a number of "waves" in entrepreneurship education, developing into many phases and now expanding exponentially. By making entrepreneurship education available to young people and adults, each and everyone have to prepare the next wave of entrepreneurs to enable, to lead and shape the firms. The time to act is now and it is time to more adequately develop entrepreneurial skills, attitudes and behaviours in our school and college systems.

This study was undertaken in Erode District, covering all8 constituencies and 6 taluks. Each and every stage of the research has been explained briefly for which Descriptive Research Design was adopted. The MBA students of all the colleges in various parts of Erode District during the period of October 2013 - March 2014 was taken as sample. About 750 students were identified and surveyed using Simple Random Sampling Technique. For the study, both primary and secondary data were collected. Structured questionnaires and interviews were used to collect the primary data.

Keywords: Entrepreneurship, Entrepreneurship Education, Entrepreneurship Initiation, Motivation factors

\section{INTRODUCTION}

"Entrepreneurship is an incredible force. It is the engine of growth, jobs and opportunity and deserved to be celebrated"

Entrepreneurship has never been more important than it is today in this time of financial crisis. However, a considerable agreement exists to stress the role of promoting entrepreneurial initiatives through education among the students, to stimulate the economic development and employment generation. The entrepreneurship education, as an initiative, can equip people to proactively pursue those opportunities available to them based on their local environments and cultures. So it is been considered that the entrepreneurial initiative can be imparted to students through their education.

\section{ENTREPRENEUR \& ENTREPRENEURSHIP}

There has been a great deal of attention paid to the subject of entrepreneurship over the past few years, stemming primarily from the discovery by economic analysts and involves the development of a business from the ground up and turning it into a profitable business. The definitions are quoted below:

$>$ According to America Heritage dictionary: "Entrepreneur is a person who organizes, operates and assumes the risk for business venture" 
According to Dr. Joseph A. Schumpeter:

"Nobody is an entrepreneur all the time; one behaves as an entrepreneur only when carrying out innovations".

He defines the concept as:

Entrepreneur $\Rightarrow$ Individual

Entrepreneurship $\Rightarrow$ Process

Entrepreneurial $\Rightarrow$ Attitudes, Skills, Behaviours

$>$ "Entrepreneurship is the journey of opportunity exploration and risk management to create value for profit and/or social good"

$$
\begin{gathered}
\text { - Ajay Bam (Berkeley's } \\
\text { Haas School of Business) }
\end{gathered}
$$

\section{NEED FOR ENTREPRENEURSHIP EDUCATION:}

Entrepreneurship Education is the one which seeks to provide students with the knowledge, skills and motivation to encourage entrepreneurial success in a variety of settings. Nowadays entrepreneurship education is been offered at all levels of schooling from primary or secondary schools to university programs. Added the National Standards for Entrepreneurship Education were also developed to prepare youth and adults to succeed in an entrepreneurial economy.

\section{OBJECTIVES OF THE STUDY:}

1. To analyze the various skills and knowledge possessed by the MBA students towards entrepreneurship.

2. To determine the factors that triggers the students towards Entrepreneurship.

3. To ascertain the role of Entrepreneurship Education in initiating entrepreneurial thoughts.

\section{REVIEW OF LITERATURE:}

1. Ernest Samwel Mwasalwiba, (2010) aimed to take stock of existing publications devoted to entrepreneurship education and assessed the alignment existing between its generic objectives, target audience, teaching methods and impact indicators. A semi-systematic literature review is applied; using six thematically separated excel data collection spreadsheets. A total of 108 articles are reviewed. It was found that scholars in this field of study, though differing in a number of definitive issues, are converging towards a single framework of entrepreneurship education and accepted that there is a shift from a start-up view to an attitude-changing perspective of entrepreneurship education. It was also noted that there is still a non-alignment between what educators and other stakeholders wish to achieve in educating for entrepreneurship with the applied pedagogical approaches, and success indicators.

2. Roya Molaei, et al, (2014) explored the effect of entrepreneurial idea dimensions along with intuitive cognitive style versus an analytical style on students' entrepreneurial intention, the data obtained from an extensive survey of 376 undergraduate students of campuses of Behavioral Sciences and Engineering at University of Teheran. The data were analyzed by the SEM using LISREL software and SPSS. According to the SEM results, the students with intuitive cognitive style, among the four dimensions of entrepreneurial idea (i.e. idea's content, volume, value, and novelty), the greatest direct effect belongs to the idea volume and idea content. It is recommended that, in order to create and increase the entrepreneurial ideas among all students, a course entitled "Entrepreneurial Idea Generation" is offered in Entrepreneurship Education Program at undergraduate and graduate level.

3. Dinis Anabela, et.al. (2013) provides important evidence for improving entrepreneurship education for young students. First, it is important to incite and develop some psychological characteristics in order to promote entrepreneurial intentions. Second, entrepreneurship curricula should jointly develop both entrepreneurial characteristics and the awareness among students about the viability of an entrepreneurial career. A sample of secondary students was chosen ranging from 14 to 15 years old. Data were collected through a questionnaire and analysed by univarite statistics and structural equations modelling (PLS) to measure the relationship between the psychological characteristics and entrepreneurial intentions. The results demonstrate there is a relationship between (some) psychological 
International Journal of Trend in Scientific Research and Development (IJTSRD) ISSN: 2456-6470

characteristics and entrepreneurial intentions. However, the model needs further development through the incorporation of behavioral characteristics through proper education.

4. Alistair R. Anderson (2011) reviewed the existing literature and conceptual developments to explore how and why universities should teach entrepreneurship. The paper largely synthesizes existing work, but conceptualizes and presents the material in a new way, which draws on the rich seam of existing literature to develop theory about enterprise education purpose and pedagogy. The paper raises awareness of the importance of the university's role for developing the right sort of entrepreneurship. It also highlights important pedagogic points that will realize the full potential of a university entrepreneurial education. The findings reported that the Universities are uniquely able to provide the right sort of education that will produce "better" entrepreneurs. In turn, these better entrepreneurs are better enabled to produce and successfully implement the innovation that drives economic growth.

\section{ANALYSIS AND INTERPRETATION:}

The data collected have been organized, classified and analyzed using a wide range of appropriate statistical tools like Mean Analysis, Chi-Square, Henry Garrett Ranking Technique, to attain the objectives of the study.

Objective 1 - To analyze the various skills and knowledge possessed by the MBA students towards entrepreneurship.

\section{HENRY GARRETT TECHNIQUE}

\section{a) Ranking the entrepreneurship knowledge from the perception of students:}

An attempt has been made to know the importance for entrepreneurship related skills and knowledge. For the purpose of this study, it has been classified into the following ten categories. The respondents were asked to rank these entrepreneurial skills and knowledge in the order of their importance. To identify the most important factor, Henry Garrett Ranking Technique was employed and the details of ranking the importance for entrepreneurship related to skills and knowledge are shown in the following table.

\section{TABLE NO. 1 - ENTREPRENEURSHIP KNOWLEDGE}

\begin{tabular}{|c|c|c|c|c|}
\hline S. No. & $\begin{array}{l}\text { Entrepreneurship } \\
\text { Knowledge }\end{array}$ & $\begin{array}{l}\text { Total } \\
\text { Score }\end{array}$ & $\begin{array}{l}\text { Mean } \\
\text { Score }\end{array}$ & Rank \\
\hline 1. & $\begin{array}{l}\text { Knowledge to seek } \\
\text { opportunities }\end{array}$ & 40757 & 54.3 & II \\
\hline 2. & $\begin{array}{l}\text { Knowledge towards } \\
\text { Goal-setting }\end{array}$ & 43970 & 58.6 & I \\
\hline 3. & $\begin{array}{l}\text { Innovative and } \\
\text { Imaginative } \\
\text { Knowledge }\end{array}$ & 38669 & 51.6 & V \\
\hline 4. & Intellectuality & 35234 & 47.0 & VIII \\
\hline 5. & $\begin{array}{l}\text { Knowledge on current } \\
\text { market trends }\end{array}$ & 40655 & 54.2 & III \\
\hline 6. & $\begin{array}{l}\text { Knowledge on } \\
\text { systematic planning }\end{array}$ & 39717 & 53.0 & IV \\
\hline 7. & $\begin{array}{l}\text { Knowledge on } \\
\text { Networking }\end{array}$ & 35693 & 47.6 & VII \\
\hline 8. & $\begin{array}{l}\text { Knowledge on legal } \\
\text { and commercial issues }\end{array}$ & 30509 & 40.7 & $X$ \\
\hline 9. & $\begin{array}{l}\text { Knowledge on latest } \\
\text { technology }\end{array}$ & 37138 & 49.5 & VI \\
\hline 10. & $\begin{array}{l}\text { Knowledge on internal } \\
\& \text { external factors } \\
\text { stimulating } \\
\& \text { affecting } \\
\text { entrepreneurship }\end{array}$ & 33136 & 44.2 & IX \\
\hline
\end{tabular}

It is inferred from the above table that, among the factors assessing entrepreneurship skills and knowledge, the major factor Knowledge towards Goal-setting ranked first with the Garrett score of 43970 points. The factors such as Knowledge to seek opportunities, Knowledge on current market trends and Knowledge on systematic planning are placed in second, third and fourth ranks with the Garrett scores of 40757, 40655 and 39717 points respectively. The factors such as Innovative and Imaginative Knowledge, Knowledge on latest technology, Knowledge on Networking, Intellectuality and Knowledge on internal \& external factors stimulating $\&$ affecting entrepreneurship are placed in fifth, sixth, seven, eighth and ninth ranks with the Garrett scores of $38669,37138,35693,35234$ and 33136 points respectively. Finally, the respondents select the last factor as Knowledge on legal and commercial issues with Garrett score of 30509 points.

It is found from the analysis that majority of the respondents, opined that the factors such as Knowledge towards Goal-setting and Knowledge to 
International Journal of Trend in Scientific Research and Development (IJTSRD) ISSN: 2456-6470

seek opportunities are prior important for entrepreneurship related knowledge.

\section{b) Ranking the entrepreneurship skills from the perception of students:}

An attempt has been made to know the survival skills of entrepreneur. For the purpose of this study, it has been classified into the below seven categories. The respondents were asked to rank these survival skills of entrepreneur in the order of their importance, for which Henry Garrett Ranking Technique was employed.

TABLE NO. 2 ENTREPRENEURSHIP SKILLS
\begin{tabular}{|c|l|c|c|c|}
\hline No. & $\begin{array}{l}\text { Entrepreneurship } \\
\text { Skills }\end{array}$ & $\begin{array}{c}\text { Total } \\
\text { Score }\end{array}$ & $\begin{array}{c}\text { Mean } \\
\text { Score }\end{array}$ & Rank \\
\hline 1. & Interpersonal Skills & 37861 & 50.5 & IV \\
\hline 2. & Leadership Skills & 45624 & 60.8 & I \\
\hline 3. & $\begin{array}{l}\text { Technological } \\
\text { Skills }\end{array}$ & 38102 & 50.8 & III \\
\hline 4. & Analytical Skills & 35295 & 47.1 & VI \\
\hline 5. & $\begin{array}{l}\text { Communication } \\
\text { Skills }\end{array}$ & 41111 & 54.8 & II \\
\hline 6. & $\begin{array}{l}\text { Problem solving } \\
\text { Skills }\end{array}$ & 37159 & 49.5 & V \\
\hline 7. & Cognitive skills & 26642 & 35.5 & VII \\
\hline
\end{tabular}

It is found from the above table that, among the survival skills of entrepreneur, the major skill Leadership Skills ranked first with the Garrett score of 45624 points. The skills such as Communication Skills, Technological Skills, Interpersonal Skills, Problem solving Skills and Analytical Skills are placed in second, third, fourth, fifth and sixth ranks with the Garrett scores of 41111, 38102, 37861, 37159 and 35295 points respectively. Finally, the respondents select the last skill as cognitive skill with Garrett score of 26642 points.

It is found from the analysis that majority of the respondents, opined that Leadership Skills and Communication Skills are the important survival skills of entrepreneur.
Objective 2 - To determine the factors that trigger the students towards Entrepreneurship

\section{PERCENTAGE ANALYSIS}

\section{a) Factors motivating the respondents towards Entrepreneurship:}

An attempt has been made to know the sources that motivated the students towards entrepreneurship.

\section{TABLE NO: 3 - FACTORS MOTIVATING THE RESPONDENTS TOWARDS ENTREPRENEURSHIP (PERCENTAGE ANALYSIS)}

\begin{tabular}{|c|c|c|c|}
\hline $\begin{array}{c}\text { Sr. } \\
\text { No. }\end{array}$ & $\begin{array}{c}\text { Factors Trigerring } \\
\text { Entrepreneurship }\end{array}$ & $\begin{array}{c}\text { No. of } \\
\text { Respondents }\end{array}$ & Percentage \\
\hline 1. & Family Member & 228 & 30.4 \\
\hline 2. & $\begin{array}{c}\text { Role Model of } \\
\text { Entrepreneurs }\end{array}$ & 156 & 20.8 \\
\hline 3. & Teacher/Mentor & 167 & 22.3 \\
\hline 4. & Fellow Students & 40 & 5.3 \\
\hline 5. & Dreams \& Desires & 159 & 21.2 \\
\hline & Total & $\mathbf{7 5 0}$ & $\mathbf{1 0 0 . 0}$ \\
\hline
\end{tabular}

It is noted from the above table that 30.4 percent of the respondents' were motivated towards entrepreneurship by family members, 20.8 percent of the respondents opined that the role model of entrepreneurs motivated them towards entrepreneurship, 22.3 percent of the respondents opined that teacher/mentors motivated them towards entrepreneurship, 5.3 percent of the respondents opined that fellow students motivated them towards entrepreneurship and 21.2 percent of the respondents opined that dreams and desires motivated them towards entrepreneurship.

It is found from the analysis that the majority (30.4\%) of the respondents' were motivated towards entrepreneurship by family members. 


\section{CHART NO: 3.1 - FACTORS MOTIVATING THE RESPONDENTS TOWARDS ENTREPRENEURSHIP}

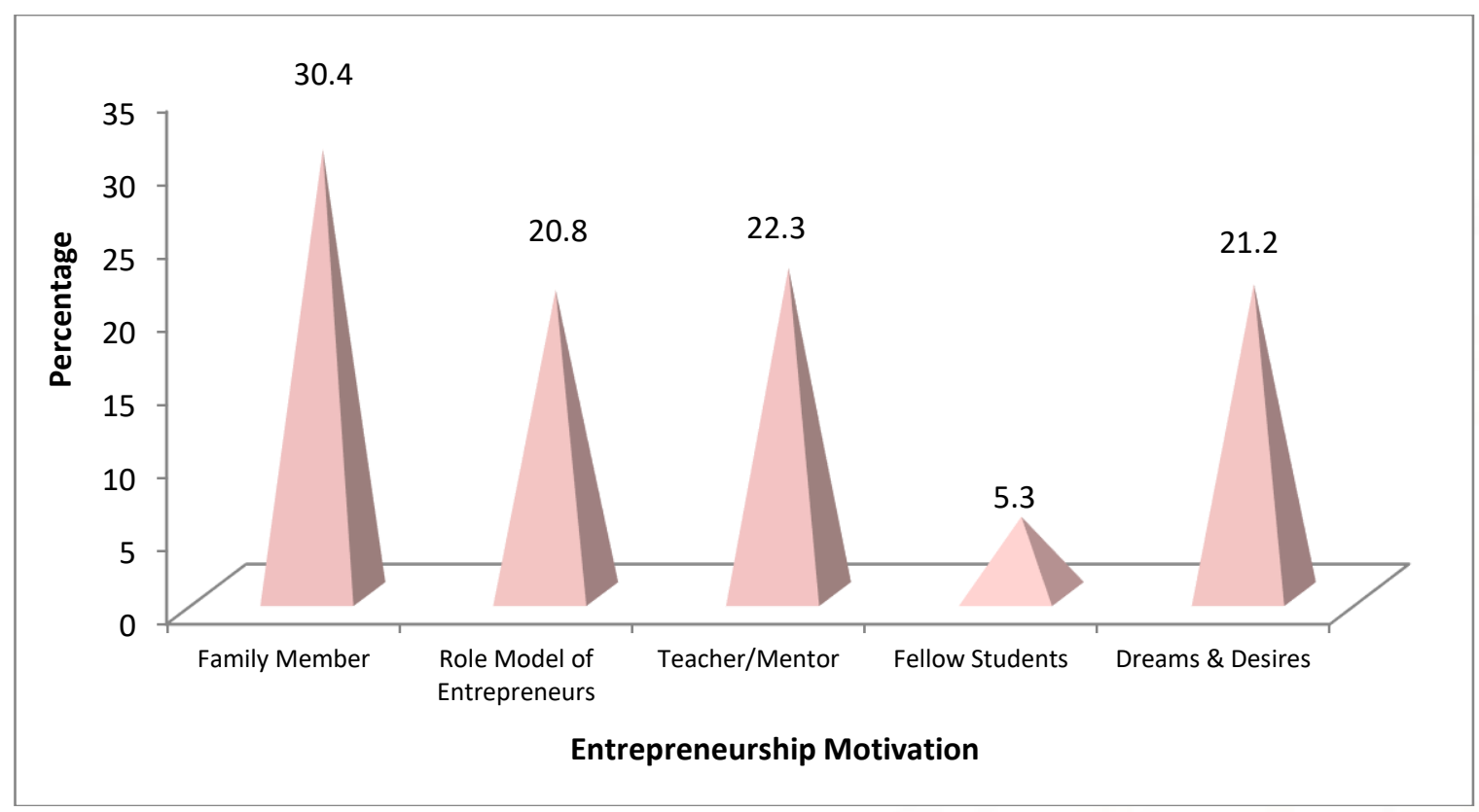

\section{CHI-SQUARE TEST}

b) Factors motivating entrepreneurship and contributions of the existing educational system:

With a view to find the degree of association between factors motivating entrepreneurship of the respondents and contributions of the existing educational system, a two-way table is prepared and is exhibited as follows.

TABLE NO: 4 - FACTORS MOTIVATING ENTREPRENEURSHIP AND CONTRIBUTIONS OF THE EXISTING EDUCATIONAL SYSTEM (TWO-WAY TABLE)

\begin{tabular}{|l|l|l|l|l|l|l|}
\hline \multirow{2}{*}{$\begin{array}{l}\text { No. } \\
\text { No. }\end{array}$} & Motivated & \multicolumn{2}{|l|}{ Level of Contribution } & Total & \multirow{2}{*}{ Mean } \\
\cline { 3 - 6 } & Low & Medium & High & & \\
\hline 1. & Family Member & $\begin{array}{l}77 \\
(33.8 \%)\end{array}$ & $\begin{array}{l}89 \\
(39.0 \%)\end{array}$ & $\begin{array}{l}62 \\
(27.2 \%)\end{array}$ & 228 & 17.1 \\
\hline 2. & $\begin{array}{l}\text { Role Model of } \\
\text { Entrepreneurs }\end{array}$ & $\begin{array}{l}37 \\
(23.7 \%)\end{array}$ & $\begin{array}{l}81 \\
(51.9 \%)\end{array}$ & $\begin{array}{l}38 \\
(24.4 \%)\end{array}$ & 156 & 17.1 \\
\hline 3. & Teacher/Mentor & $\begin{array}{l}58 \\
(34.7 \%)\end{array}$ & $\begin{array}{l}66 \\
(39.5 \%)\end{array}$ & $\begin{array}{l}43 \\
(25.7 \%)\end{array}$ & 167 & 17.2 \\
\hline 4. & Fellow Students & $\begin{array}{l}11 \\
(27.5 \%)\end{array}$ & $\begin{array}{l}22 \\
(55.0 \%)\end{array}$ & $\begin{array}{l}7 \\
(17.5 \%)\end{array}$ & 40 & 16.9 \\
\hline 5. & Dreams \& Desires & $\begin{array}{l}56 \\
(35.2 \%)\end{array}$ & $\begin{array}{l}48 \\
(30.2 \%)\end{array}$ & $\begin{array}{l}55 \\
(34.6 \%)\end{array}$ & 159 & 17.5 \\
\hline & Total & $\mathbf{2 3 9}$ & $\mathbf{3 0 6}$ & $\mathbf{2 0 5}$ & $\mathbf{7 5 0}$ & \\
\hline
\end{tabular}

It is found from the above table that the high level of contributions of the existing educational system was the highest (34.6\%) among the students who motivated by their dreams and desires and the same was the lowest (17.5\%) among the students who motivated by their fellow students. The percentage of medium level of contributions of the existing educational system was the highest (55.0\%) among the students who motivated by their fellow students and the lowest (30.2\%) among the students who motivated by their dreams and desires. On the other hand, the percentage of low level of contributions of the existing educational system was the highest (35.2\%) among the students who motivated by their 
International Journal of Trend in Scientific Research and Development (IJTSRD) ISSN: 2456-6470

dreams and desires and the lowest $(23.7 \%)$ among the students who motivated by their role model of entrepreneurs.

Further, it is found that MBA students have attained maximum (17.5) level of contributions of the existing educational system among the students who motivated by their dreams and desires.

In order to find the relationship between motivation to be an entrepreneurship and contributions of the existing educational system, a hypothesis has been formulated and tested by using chi-square test and the results are discussed in the following table.

$\mathrm{H}_{0}$ : There is no significant relationship between motivation to be an entrepreneurship of the respondents and contributions of the existing educational system.

$\mathrm{H}_{1}$ : There is a close significant relationship between motivation to be an entrepreneurship of the respondents and contributions of the existing educational system.

TABLE NO: 5 - FACTORS MOTIVATING ENTREPRENEURSHIP AND CONTRIBUTIONS OF THE EXISTING EDUCATIONAL SYSTEM (CHI- SQUARE TEST)

\begin{tabular}{|c|c|c|c|c|}
\hline Factor & $\begin{array}{c}\text { Calculate } \\
\mathbf{d} \chi^{2} \\
\text { Value }\end{array}$ & $\begin{array}{c}\text { Table } \\
\text { Value }\end{array}$ & $\begin{array}{c}\text { D. } \\
\text { F }\end{array}$ & Remarks \\
\hline $\begin{array}{c}\text { Motivated } \\
\begin{array}{c}\text { Entrepreneursh } \\
\text { ip }\end{array}\end{array}$ & 21.216 & $\begin{array}{c}20.09 \\
0\end{array}$ & 8 & $\begin{array}{c}\text { Significa } \\
\text { nt at 1\% } \\
\text { level }\end{array}$ \\
\hline
\end{tabular}

It is stated from the above table that the calculated chi-square value is greater than the table value the result is significant at $1 \%$ level. So, the null hypothesis is rejected.

It is concluded that there is a close significant relationship between motivation to be an entrepreneurship of the respondents and contributions of the existing educational system.

\section{Objective 3 - To ascertain the role of Entrepreneurship Education in initiating entrepreneurial thoughts}

\section{PERCENTAGE ANALYSIS:}

\section{a) Contributions of the existing educational system towards entrepreneurship development}

An attempt has been made to know the opinion of the respondents regarding the contributions of the existing educational system towards entrepreneurship development. For the purpose of this study, it has been classified into the following eight categories and the details are furnished in the following table.

\section{TABLE NO: 6 - CONTRIBUTIONS OF THE EXISTING EDUCATIONAL SYSTEM TOWARDS ENTREPRENEURSHIP DEVELOPMENT (PERCENTAGE ANALYSIS)}

\begin{tabular}{|c|c|c|c|c|c|c|}
\hline No. & Personality Changes & SDA & DA & $\mathbf{N}$ & A & SA \\
\hline 1. & Fostering the entrepreneurial spirit & $\begin{array}{l}5 \\
(0.7 \%) \\
\end{array}$ & $\begin{array}{l}29 \\
(3.9 \%) \\
\end{array}$ & $\begin{array}{l}178 \\
(23.7 \%)\end{array}$ & $\begin{array}{l}305 \\
(40.7 \%)\end{array}$ & $\begin{array}{l}233 \\
(31.1 \%)\end{array}$ \\
\hline 2. & Encouraging innovative thoughts & $\begin{array}{l}5 \\
(0.7 \%) \\
\end{array}$ & $\begin{array}{l}35 \\
(4.7 \%) \\
\end{array}$ & $\begin{array}{l}135 \\
(18.0 \%)\end{array}$ & $\begin{array}{l}355 \\
(47.3 \%)\end{array}$ & $\begin{array}{l}220 \\
(29.3 \%)\end{array}$ \\
\hline 3. & Development Risk Taking ability & $\begin{array}{l}16 \\
(2.1 \%)\end{array}$ & $\begin{array}{l}50 \\
(6.7 \%) \\
\end{array}$ & $\begin{array}{l}218 \\
(29.1 \%)\end{array}$ & $\begin{array}{l}230 \\
(30.7 \%)\end{array}$ & $\begin{array}{l}236 \\
(31.5 \%)\end{array}$ \\
\hline 4. & Developing self efficacy & $\begin{array}{l}14 \\
(1.9 \%)\end{array}$ & $\begin{array}{l}71 \\
(9.5 \%) \\
\end{array}$ & $\begin{array}{l}148 \\
(19.7 \%)\end{array}$ & $\begin{array}{l}308 \\
(41.1 \%)\end{array}$ & $\begin{array}{l}209 \\
(27.9 \%)\end{array}$ \\
\hline 5. & Behavioural Changes & $\begin{array}{l}26 \\
(3.5 \%)\end{array}$ & $\begin{array}{l}46 \\
(6.1 \%)\end{array}$ & $\begin{array}{l}194 \\
(25.9 \%)\end{array}$ & $\begin{array}{l}269 \\
(35.9 \%)\end{array}$ & $\begin{array}{l}215 \\
(28.7 \%)\end{array}$ \\
\hline
\end{tabular}


International Journal of Trend in Scientific Research and Development (IJTSRD) ISSN: 2456-6470

\begin{tabular}{|c|c|c|c|c|c|c|}
\hline 6. & Attitudinal Changes & $\begin{array}{l}20 \\
(2.7 \%)\end{array}$ & $\begin{array}{l}60 \\
(8.0 \%)\end{array}$ & $\begin{array}{l}181 \\
(24.1 \%)\end{array}$ & $\begin{array}{l}299 \\
(39.9 \%)\end{array}$ & $\begin{array}{l}190 \\
(25.3 \%)\end{array}$ \\
\hline 7. & Developing ethical and traditional values & $\begin{array}{l}33 \\
(4.4 \%)\end{array}$ & $\begin{array}{l}87 \\
(11.6 \%)\end{array}$ & $\begin{array}{l}201 \\
(26.8 \%)\end{array}$ & $\begin{array}{l}258 \\
(34.4 \%)\end{array}$ & $\begin{array}{l}171 \\
(22.8 \%)\end{array}$ \\
\hline 8. & Self Management & $\begin{array}{l}25 \\
(3.3 \%)\end{array}$ & $\begin{array}{l}52 \\
(6.9 \%)\end{array}$ & $\begin{array}{l}116 \\
(15.5 \%)\end{array}$ & $\begin{array}{l}251 \\
(33.5 \%)\end{array}$ & $\begin{array}{l}306 \\
(40.8 \%)\end{array}$ \\
\hline
\end{tabular}

It is stated from the above table that the respondents have strongly agreed that the contributions of the existing educational system towards entrepreneurship development; stimulates the personality changes such as development of risk taking ability and self management as 31.5 and 40.8 percent respectively. On the other hand, the respondents have agreed towards the personality changes like fostering the entrepreneurial spirit, encouraging innovative thoughts, developing self efficacy, behavioural changes, attitudinal changes, developing ethical and traditional values as 40.7, 47.3, 41.1, 35.9, 39.9 and 34.4 percent respectively. It is found from the analysis that the majority $(47.3 \%)$ of the respondents agreed that; encouraging innovative thoughts among the students, stimulate the entrepreneurship development which should be the prime contribution of the existing educational system.

\section{b) Teaching initiatives that encourages the entrepreneurial spirit}

An attempt has been made to know the opinion of the respondents regarding teaching initiatives that encourages the entrepreneurial spirit among the students, for which it has been classified into the following five categories.

\section{TABLE NO: 7 - TEACHING INITIATIVES THAT ENCOURAGES ENTREPRENURIAL SPIRIT (PERCENTAGE ANALYSIS)}

\begin{tabular}{|c|c|c|c|}
\hline S.No & $\begin{array}{l}\text { Teaching } \\
\text { Initiatives } \\
\end{array}$ & $\begin{array}{l}\text { No. of } \\
\text { Respondents }\end{array}$ & Percentage \\
\hline 1. & $\begin{array}{l}\text { Assignment } \\
\text { and projects }\end{array}$ & 370 & 49.3 \\
\hline 2. & $\begin{array}{l}\text { Business } \\
\text { Games }\end{array}$ & 453 & 60.4 \\
\hline 3. & Case Studies & 323 & 43.1 \\
\hline 4. & $\begin{array}{l}\text { Industry } \\
\text { Academia } \\
\text { Interaction }\end{array}$ & 297 & 39.6 \\
\hline 5. & $\begin{array}{l}\text { Psychological } \\
\text { Counselling }\end{array}$ & 244 & 32.5 \\
\hline
\end{tabular}

It is noted from the above table that majority of 60.4 percent of the respondents opined that entrepreneurial spirit is initiated from business games and 32.5 percent of the respondents opined that entrepreneurial spirit is encouraged from psychological counselling.

It is found from the analysis that the majority (60.4\%) of the respondentsopined that business games mostly initiates the entrepreneurial spirit.

\section{CONCLUSION:}

It is known that innovation and entrepreneurship provides a way forward in solving the global challenges of the 21 st century either in creating jobs or in generating renewed economic growth. This study thus provides a platform to know more about the importance of providing entrepreneurship education to the students with a wide range of imparting entrepreneurial knowledge and skills to promote higher interest within them. We can conclude the study by stating that, for creating a resilient Indian economy, the entrepreneurship initiatives and motivation is been highly essential which can be achieved only by means of providing entrepreneurial education.

\section{BIBLIOGRAPHY:}

1) Alistair Anderson .R, (2011). The university's role in developing Chinese entrepreneurship. Journal of Chinese Entrepreneurship, 3 (3), 175 $-184$.

2) Basu, A., Virick, M. (2010): Assessing Entrepreneurial Intentions Amongst Students:A Comparative Study, San Jose State University

3) Dinis Anabela, do Paço Arminda, Ferreira João, Raposo Mário, Gouveia Rodrigues Ricardo (2013). Psychological characteristics and entrepreneurial intentions among secondary students, Education + Training, 55 (8/9), 763780.

4) Ernest Samwel Mwasalwiba (2010). Entrepreneurship education: a review of 
itsobjectives, teaching methods, and impact indicators, Education + Training,52 (1), 20-47.

5) Henrik berglund, karlwennberg, (2006), Creativity among entrepreneurship students: Comparing engineering and business education, 16(5), 2-9.

6) Roya Molaei , Mohammad Reza Zali , Mohhammad Hasan Mobaraki JahngirYadollahi Farsi (2014). The impact of entrepreneurial ideas and cognitive styleon students entrepreneurial intention. Journal of Entrepreneurship in EmergingEconomies, 6 (2), 140-162. 